\title{
The Politics of Higher Education for Refugees in a Global Movement for Primary Education
}

\author{
SARAh Dryden-Peterson
}

\begin{abstract}
In the context of Education for All (EFA) and the Millennium Development Goals (MDG), global movements for expanded access to education have focused on primary education. In refugee situations, where one-quarter of refugees do not have access to primary school and two-thirds do not have access to secondary school, donors and agencies resist supporting higher education with arguments that, at great cost, it stands to benefit a small and elite group. At the same time, refugees are clear that progression to higher levels of education is integrally connected with their future livelihoods and future stability for their regions of origin. This paper examines where higher education fits within a broader framework of refugee education and the politics of its provision, with attention to the policies and priorities of UN agencies, NGOs, national governments, and refugees themselves.
\end{abstract}

\section{Résumé}

Dans le contexte des initiatives Éducation pour tous et Objectifs du millénaire pour le développement, les mouvements internationaux pour élargir l'accès à l'éducation sont axés sur l'enseignement primaire. Dans le cas des réfugiés, dont le quart n'a pas accès à l'école primaire et les deux tiers, à l'école secondaire, les donateurs et les agences hésitent à soutenir l'éducation supérieure arguant que celle-ci, d'emblée plus coûteuse, ne profitera qu'à un groupe restreint et privilégié. Parallèlement, les réfugiés croient fermement que la progression vers de plus hauts niveaux d'éducation fait partie intégrante d'un gagnepain futur et d'une éventuelle stabilité dans leurs régions d'origine. Cet article examine où se situe l'éducation postsecondaire dans un cadre élargi de l'éducation des réfugiés ainsi que les politiques pour sa prestation, et s'attarde sur les politiques et les priorités des agences des Nations Unies, des ONG, des gouvernements nationaux et des réfugiés eux-mêmes.

\section{Introduction}

Access to education is a basic human right and a central component of development strategies linked to poverty reduction, holding promises of stability, economic growth, and better lives for children, families, and communities. In 1948, the Universal Declaration of Human Rights recognized compulsory education as a universal entitlement. The Convention on the Elimination of All Forms of Discrimination Against Women (1979) called for no discrimination in educational provision for men and women, and the Convention on the Rights of the Child (1989) affirmed the right of all children to free and compulsory primary education (Article 28.1.a). The global education movement is built on these visions and is expressed in the Dakar Education for All Framework for Action (2000) and the Millennium Development Goals (2000). These frameworks specify the need to establish quality access to education for all and to do so by 2015.

Higher education has remained largely outside of the global education movement, within which the focus has instead been on primary education. Through a synthesis of literature and policy analysis, this paper explores the place of higher education for refugees in situations where vast numbers of children do not have access even to primary school. First, I discuss the politics of provision of higher education through the lens of the global education movement and its particular commitment to equity. Second, I survey the state of educational access for refugees at all levels of education, placing higher education within a continuum of education including primary, secondary, and tertiary education. Finally, I examine the particular importance of higher education for refugees and how it can contribute to the global 
education movement, including building upon the commitment to equity.

\section{Higher Education and the Global Education Movement}

Access to a complete course of quality primary education is the main objective of the global education movement as outlined in the Dakar Framework for Action and the Millennium Development Goals. ${ }^{1}$ There is some emphasis on secondary education, life skills training, and adult literacy and continuing education, ${ }^{2}$ but higher education is not mentioned in these seminal documents. The global priorities for education are rooted in both the geography and the philosophy of the movement. They are borne of a recognition that the greatest challenges to educational access are in the least developed countries (LDCs), geographically centred in sub-Saharan Africa and South Asia, particularly in countries affected by conflict or undergoing reconstruction. ${ }^{3}$

There has been remarkable progress in many countries toward educational access for all, such that, globally, the number of out-of-school children decreased from 115 million to fewer than 70 million between 2000 and $2010 .{ }^{4}$ Progress in conflict-affected states, however, has been more difficult; UNESCO estimates that 28 million out-of-school children live in low and lower-middle income conflict-affected states, which represents 42 per cent of the world's total. ${ }^{5}$ In Democratic Republic of Congo (DRC), for example, only 52 per cent of children are enrolled in primary school, ${ }^{6}$ and just 49 per cent of those beginning primary school complete the primary cycle. ${ }^{7}$ Further, countries that have recently universalized access to primary education have often done so at the expense of quality, such that even children enrolled in school are not gaining the desired skills, knowledge, and competencies. ${ }^{8}$ In this situation, the immediacy and pressing nature of barriers to accessing quality primary education overshadow concurrent barriers in higher education.

The numbers of children without access to primary education in much of the global South necessarily narrows the pipeline to higher education and raises philosophical questions related to equity. Fewer than three per cent of the eligible age group have access to higher education in Africa, ${ }^{9}$ what sociologist Martin Trow would characterize as an "elite" system of higher education. ${ }^{10}$ In the conflictaffected DRC, for example, only 0.4 per cent of the population accesses university, ${ }^{11}$ and 70 per cent of higher education institutions are in the capital city, Kinshasa. ${ }^{12}$ While Altbach is confident that all education systems globally are moving toward mass enrolment (between 20 and 30 per cent) and even universal enrolment (more than 30 per cent), ${ }^{13}$ many LDCs, especially in sub-Saharan Africa and those that are affected by conflict, continue to lag behind in this "massification."14

Despite the small reach of higher education in the global South, the educational policies of many of these countries strongly favour higher education. Using 1999 data from the UNESCO "Statistical Yearbook," Su reports that in non-OECD countries, the relative education expenditure is "stunningly" higher for tertiary than primary. In Malawi, for example, public expenditure per pupil as a proportion of GNP per capita is 9 per cent at primary, 27 per cent at secondary, and 1,580 per cent at tertiary; the relative ratio of education expenditure is therefore 3 between secondary and primary and 176 between tertiary and primary. ${ }^{15}$ In post-genocide Rwanda, higher education was conceived as the primary mechanism of economic development such that in 2000, higher education funding made up one-third of the budget allocation to education. While higher education in Rwanda has thrived, the primary education system still falters. ${ }^{16}$

Higher education is indeed expensive, and state support for it reduces resources for other educational endeavours. Moreover, it perpetuates inequalities in already divided societies. Psacharopoulos and Patrinos show that the returns to education in non-OECD countries are significantly higher at the primary level and moderately higher at the secondary level than at the tertiary level. ${ }^{17}$ Research is conclusive that mass expansion of higher education reduces income inequality only when labour market conditions are right. ${ }^{18}$ In LDCs, subsidies for higher education are often correlated with higher GINI coefficients, ${ }^{19}$ which indicates increased inequality, although this is beginning to change in new knowledge economies, where there is rapid expansion in employment opportunities involving the production of ideas and information. ${ }^{20}$ In cases of underdevelopment and of conflict, the creation and expansion of knowledge economies is rare as well as slow. In these contexts, the wealthy benefit disproportionately from public investment in higher education due to what Su calls "exclusive participation"21 of the wealthy and limited access for others. Existing policies favouring higher education in many LDCs are not based in forward-looking economic policies and instead can only be explained by the political power of dominant elites who influence budget allocations in favour of subsidizing higher education for their own children.

Large-scale investment in higher education in countries of the global South, particularly in conflict-affected states, is conceived of as being at the expense of investment in underresourced primary and secondary systems. Given that this investment does not appear to match the goals of equity that underpin the Dakar Framework for Action and the Millennium Development goals, higher education in these contexts is not a priority for donors. 
Figure 1. Refugee participation in primary and secondary school (2009) as compared to global participation (2008) expressed in Gross Enrolment Ratios (GER)

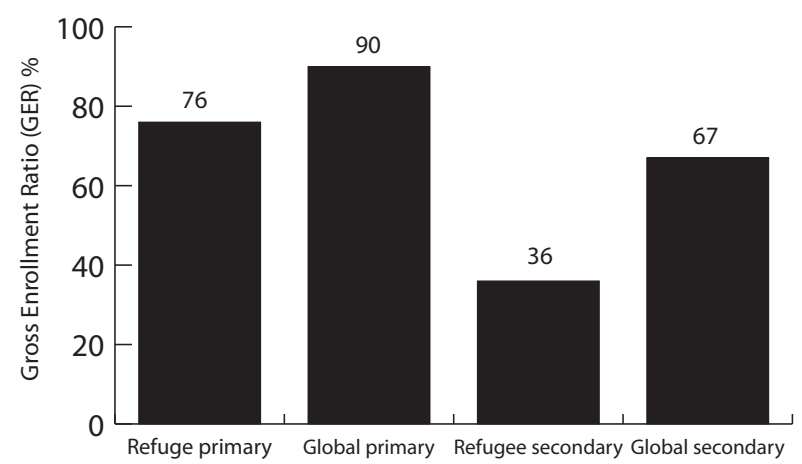

Source: Sarah Dryden-Peterson, "Refugee Education: A Global Review" (Geneva: UNHCR, 2011, forthcoming).

\section{Educational Access for Refugees}

Refugees are one group of conflict-affected people who remain out of school in large numbers. In Dakar, in 2000, conflict and disasters were explicitly acknowledged as obstacles to the achievement of Education for All (EFA) targets, ${ }^{22}$ and the evidence clearly points in that direction. Article 22 of the 1951 Convention Relating to the Status of Refugees binds the signatory states to "accord to refugees the same treatment as is accorded to nationals with respect to elementary education [and] treatment as favourable as possible ... with respect to education other than elementary education." 23

Despite this provision, refugee participation in education is strikingly low. ${ }^{24}$ In 2009 , the average primary school Gross Enrollment Ratio (GER) ${ }^{25}$ of six- to eleven-year-olds was 76 per cent, across ninety-two camps and forty-seven urban settings. The average secondary school GER of twelveto seventeen-year-olds was much lower at 36 per cent, across ninety-two camps and forty-eight urban settings. As a point of comparison, in 2008, the global primary school GER was 90 per cent, and the global secondary school GER was 67 per cent (see Figure 1). While GERs vary by country, GERs for refugees are generally lower than for nationals. ${ }^{26}$

Despite continued low participation, the current educational enrolments of refugees represent an upward trend, reflecting a new emphasis on education in refugee situations. Until recently, education for refugees received very little attention, with the focus on "life-saving" interventions related to food, shelter, and health. There are a number of reasons for which education is now on the agenda. ${ }^{27}$ In particular, the nature of contemporary conflicts means that refugee situations are increasingly protracted, such that refugees can spend their entire school-age years displaced. In addition, UNHCR and its donors have increasingly viewed refugee education as an issue of security, particularly in the protective role education can have for refugee children and youth in meeting psychosocial needs, providing space for conveying survival messages, and developing skills for conflict resolution and peacebuilding. ${ }^{28}$

Further, this shift within refugee education has been driven by tremendous growth in the larger field of "education in emergencies." The Inter-Agency Network for Education in Emergencies (INEE), conceived at the World Education Forum in Dakar in 2000, has led this movement. It is an open network of 5,700 representatives from NGOs, UN agencies, donor agencies, governments, academic institutions, schools, and affected populations. ${ }^{29}$ The INEE Minimum Standards, first created in 2004 and updated in $2010,{ }^{30}$ are now the normative framework for practice in the field, including for refugee education. The Minimum Standards for Education are also a companion to the Sphere Project Humanitarian Charter and Minimum Standards ${ }^{31}$ and, since 2006, there has been an Inter-Agency Standing Committee (IASC) Global Education Cluster, both serving to bring legitimacy to the role of education in humanitarian response.

Increased attention to education for refugees represents two critical shifts in the conceptualization of humanitarian assistance. Euripides wrote in Medea in $431 \mathrm{BC}$ that " $\mathrm{t}]$ here is no greater sorrow on this earth than the loss of one's natural land." Land no doubt is a connection to one's home place, to ancestors, and to a sense of belonging; perhaps more importantly, it has provided for families' future security. The importance of "one's natural land" has guided refugee policy for much of the twentieth century, with UNHCR's preferred durable solution as voluntary repatriation to one's home country. Increasingly, however, and more so in knowledge-based economies, future security is less tied to land, and UNHCR policy has begun to reflect a second possible durable solution of local integration into the country of asylum. ${ }^{32}$ This shift in thinking and policy includes the provision of education, which is often perceived on the development side of a relief-to-development aid continuum. ${ }^{33}$

Moreover, availability of education for refugees reflects what refugee families seek. It is not uncommon for community leaders to ask the World Food Programme (WFP) to provide teachers additional food rations to encourage them to stay in the community and play a role in educating the children; ${ }^{34}$ or for parents to sell their food rations to pay for their children's school fees. ${ }^{35}$ A refugee from Kenya explains that "[i]n Africa, in the olden times, you could give your children land as an inheritance ... . Now in Africa ... 
there's no land, people are many. So the only inheritance you can give a child is education." ${ }^{36}$ Refugees have long been arguing that future security-economic, political, and social-is inherently connected to skills, capacities, and knowledge that can accompany an individual no matter where they may be geographically. In other words, future security and livelihoods are tied to education and represent a critical element of humanitarian assistance. ${ }^{37}$

UNHCR's Education Strategies, 2007-2009 and 20102012, reflect these shifts in thinking about the education of refugees and emphasize the right to education for every child, youth, and adult of concern to UNHCR. ${ }^{38}$ UNHCR has focused on access to education and quality of education as the central elements of ensuring the basic right to education. Given UNHCR's central mandate for refugee protection, a third element frames the Education Strategy: protection. Despite these strategic priorities, there are limited human and financial resources available for refugee education within UNHCR. Within the entire organization there are only two education officer positions, with one of them created just this year (2011). Further, the global education budget in 2010 represented only 4 per cent of the total comprehensive UNHCR budget, down from 8 per cent in 2008. In 2010, available funding covered 60 per cent of the assessed needs; in 2011, available funding covered only 39 per cent of the assessed need and, in 2012, available funding is again expected to cover 39 per cent of the assessed need. ${ }^{39}$

In an environment where resources are so limited and where primary school completion remains rare, there has been little attention to higher levels of education for refugees. In 2010, primary education accounted for 27 per cent of the UNHCR education budget; post-primary activities, including tertiary scholarships, vocational scholarships, secondary education, and vocational training accounted for 20 per cent. ${ }^{40}$ From available data, the amount allocated to tertiary education in 2010 cannot be disaggregated; however, in the 2012 budget analysis, tertiary scholarships account for 4 per cent of UNHCR's education budget. ${ }^{41}$

The lack of focus on tertiary education was not always the case within UNHCR. ${ }^{42}$ Until the mid-1980s, UNHCR devolved responsibility for primary education to refugee communities, focusing human and financial resources on post-primary education. For example, the number of post-secondary scholarships increased from about 1,000 in 1966 to over 1,200 in 1987 , and to 3,950 by $1987,{ }^{43}$ with direct funding from UNHCR and from other organizations such as the World University Service, World Council of Churches, Lutheran World Federation, and the Commonwealth Secretariat. ${ }^{44}$ Yet, in UNHCR's Education Strategy 2010-2012, post-primary education refers to secondary education and vocational and skills training; higher education is not mentioned. ${ }^{45}$ At present, in terms of the politics of aid, even secondary education is difficult for UNHCR to support, and "the main challenge for UNHCR [in tertiary education] is to overcome donor reluctance in funding scholarship programmes" 46 as "most donors focus on primary education." 47

Access to higher education outside of humanitarian structures is also difficult. Application processes typically require documentation that refugees may not have, including birth certificates, school diplomas, and examination results. In countries of first asylum, refugees who seek to access higher education are often treated by national institutions as foreign students, with the exorbitant fees that this status usually entails. ${ }^{48}$ In addition, some universities have enrolment quotas, giving priority to nationals. Further, there are sometimes matriculation restrictions that serve to limit enrolment by certain refugee groups such as in the case of Makerere University in Uganda, which in 2005 did not accept translations of high school diplomas, making it impossible for anyone educated in DRC with a Frenchlanguage diploma, for example, to enter the university. ${ }^{49}$

Despite these challenges, the 2007 Executive Committee Conclusion on Children at Risk recognized the need to "promote access to post-primary education wherever possible and appropriate." 50 In addition, the 2008 High Commissioner's dialogue on protracted refugee situations identified the importance of access to tertiary education for refugees in long-term displacement. ${ }^{51}$ Furthermore, the UNHCR Education Policy Commitments, first published in 2003, state that UNHCR will "safeguard the right of refugees to education ... which include $[s]$... . equitable access to appropriate learning for youth and adults ... Moreover, UNHCR will advocate for tertiary education and will support the effective use of resources donated for this purpose." 52

There are several tertiary scholarship programs for refugees, including through the World University Service of Canada (WUSC) and the Windle Trust. In addition, there are a growing number of programs that provide post-secondary opportunities to refugees through a combination of scholarships and distance education, including by the Jesuit Refugee Service in East Africa and the Australian Catholic University on the Thai-Burma border. These programs are mostly ad hoc, with no global coordination and, as they are also new, little has been documented about their processes and outcomes.

Formal and global support to higher education for refugees is exclusively through the DAFI Program (DAFI is the German acronym for the Albert Einstein German Academic Refugee Initiative), administered by UNHCR. This program is completely separate from broader UNHCR education 
policies and strategies and reaches a relatively small number of refugees. As explained in the 2007-2009 UNHCR Education Strategy, the program "only makes tertiary education accessible for the most deserving refugees." 53 These students, from necessity, are those who have previously had access to the resources to allow them to complete secondary school and, although data are not available, likely represent families with higher social, human, and financial capital.

Since its inception in 1992, the DAFI program has funded approximately 5,000 students from seventy countries of origin in seventy-one host countries. ${ }^{54}$ In 2008, there were 1,779 DAFI scholars. ${ }^{55}$ The UNHCR Education Strategy 2010-2012 makes clear that "there is a need to expand the scope of scholarships and the number of beneficiaries through the future establishment of similar programmes." 56 Indeed, there is high demand for these scholarships, and UNHCR generally receives between ten and thirty applications for each scholarship that is available. In some countries, acceptance rates for DAFI scholarships are 2 per cent, and many students approach UNHCR for scholarships even in countries where none are available. ${ }^{57}$

\section{Refugees and Higher Education: A Way Forward within the Global Education Movement}

The reluctance by donors in general and by UNHCR in particular toward including higher education within educational programming for refugees parallels the general trend toward an emphasis on primary education in the global education movement, as shaped by Education for All and the Millennium Development Goals. Signalling the move away from post-secondary education in the mid-1980s, a review of UNHCR's education programs concluded that post-primary scholarship "assistance requires a disproportionate share of resources for a small amount of refugees both in terms of staff time and project funds ... . In a way, scholarships have a tremendous potential for creating an elite group, long accustomed to privileged treatment." 58

Indeed, in the conflict-affected regions where refugees live, access to primary education is, as explained above, extremely low. Further, only 37 per cent of camp-based refugees have access to secondary school and, even though students in search of secondary education often move to urban areas, urban refugees also face great challenges of access, with only 31 per cent of secondary-school age refugees enrolled. ${ }^{59}$ In the settings where refugees live, comprehensive and accessible systems of primary and secondary education are rare, making equitable admissions strategies for higher education difficult. ${ }^{60}$

Yet just as within the broader global education movement, lack of investment in higher education is a double-edged sword. On the one hand, prioritizing resources for primary and secondary education better meets the needs of the vast number of children and youth who do not have access to these levels of education. It addresses equity goals over the short term. On the other hand, ignoring the development of higher education has negative long-term consequences both for individuals and society. For example, recent research by the World Bank concludes that private returns to tertiary education are often equal to the private returns to primary education, in that each additional year can yield wages 10 to 15 per cent higher. ${ }^{61}$ While these private returns are often inequitably distributed, the economic growth generated by the high-level skills cultivated through higher education can also have widespread societal benefits. The World Bank presents evidence that a one-year increase in average higher education levels would raise the annual growth of Gross Domestic Product (GDP) in sub-Saharan Africa by 0.39 percentage points while simultaneously increasing the long-run level of African GDP per capita by 12 percent. ${ }^{62}$ Given current access to higher education in many LDCs, this increase in average education levels is a long way off, yet these individual and societal benefits underscore the importance of attention to this sector of education within the global education movement.

There are three further reasons why the provision of higher education for refugees, in particular, is critical to the overall goals of the global education movement, particularly its commitment to equity. First, higher education, like primary and secondary, is an instrument of protection in refugee contexts. The recognition by donors, agencies, and refugees themselves of the protective role education can play has translated into a funding priority particularly at the primary level. There is, however, also a growing recognition of the protective role of education for youth in conflict settings. ${ }^{63}$ Reflecting this understanding, US President Obama's much-publicized Global Engagement Initiative includes a component to engage youth in the Muslim world through education as a peacebuilding and counter-terrorism endeavour. ${ }^{64}$ Indeed, for youth, the protective role played by access to secondary and higher education includes the provision of productive post-primary opportunities for positive growth and development and "keeping them out of military service." 65

Second, and related, access to higher education contributes to the rebuilding of individual refugees' lives and the realization of durable solutions. The 1989 Convention on the Rights of the Child (CRC), in Article 29, binds states to "make higher education accessible to all on the basis of capacity by every appropriate means,"66 and the INEE Minimum Standards advocate equal access to the education that each individual student needs, be that primary school or university. ${ }^{67}$ Refugees who have completed secondary 
school almost universally voice the desire to attend university, as the Women's Refugee Commission found among Iraqi refugees in Jordan, for example. 68 This desire may be linked to possible economic benefits made more likely through further education. It may also be an alternative to the labour market, since "if access to the labor market is limited for young people, as it often is in situations of emergency and reconstruction, they need the stimulus and challenge of education to absorb their energies and lessen their frustrations and anxiety about the future." ${ }^{\prime 69}$ In both cases, the opportunity of education provides refugees with the ability to think about the future. ${ }^{70}$ Unlike a focus on survival, which generally reduces people to passive recipients and does not recognize the human thirst for knowledge acquisition that enables one to think about the future and to plan and strategize for one's family, experiences with higher education allow for a shift in thinking toward considerations of the possible and potential. ${ }^{71}$

Third, higher education is a tool of reconstruction. Investment in higher education not only meets the needs of individual refugees and their individual durable solutions but also contributes to the development of the human and social capital necessary for future reconstruction and economic development in countries or regions of origin. ${ }^{72} \mathrm{~A}$ study of the DAFI program for Afghan refugees, for example, demonstrates "a direct link between a refugee programme focused on tertiary education and national reconstruction." In particular, refugees who had access to higher education found it more viable to move back home post-conflict and did so early in the repatriation process. The study further shows that over 70 per cent work as civil servants or as NGO managers, filling much-needed roles in a society in the process of rebuilding. ${ }^{73}$ Further, in 2008, approximately 6 per cent of DAFI students were engaged in teacher training activities. ${ }^{74}$ A cadre of teachers with this kind of training is essential for rebuilding an education system, often a central component of post-conflict reconstruction..$^{75}$ So while a focus on primary education may be logical when viewed narrowly through a lens of equity, a universal-and equitable-system of primary education requires teachers who are produced in the secondary and tertiary systems. ${ }^{76}$

$$
* * *
$$

In conclusion, the provision of higher education for refugees is clearly in need of attention within the global education movement. In LDCs and particularly in conflictaffected countries, higher education has been largely ignored, with the focus of educational development and aid aimed at meeting the Education for All and Millennium Development Goal targets of primary education. Higher education for refugees, most of whom live in LDCs, has followed this same pattern. The choice between investment in primary and higher education is, in many ways, a zerosum game. Yet this conceptualization conflicts with the reality that the continuum of an education system, from the primary level and including higher education, requires investment to promote both individual development and national and regional reconstruction. ${ }^{77}$ In the case of refugees, this investment requires the financial commitment of international donors in order to build the institutional capacity of UNHCR for higher education and to support other initiatives by universities and NGOs. The discussion about trade-offs between primary and higher education parallels broader discussions in the humanitarian field about emergency versus development priorities. ${ }^{78}$ Just as in that debate, there is evidence that a simultaneous focus on all levels of education-a systems-building approach-renders important benefits for both individuals and society. ${ }^{79}$ Resources are always limited and decisions necessary; however, a longterm view from the outset can result in more effective shortand long-term outcomes, including the investments that might be made to ensure an equitable higher education provision that meets the needs of individual refugees and the societies to which they hope to contribute, no matter where their futures may be.

\section{Notes}

1. United Nations, "Millennium Development Goals Report 2009" (New York: United Nations, 2009); UNESCO, “The Dakar Framework for Action: Education for All: Meeting Our Collective Committments" (Paris: UNESCO, 2000).

2. UNESCO, "The Dakar Framework for Action: Education for All: Meeting Our Collective Committments," 8.

3. Ibid., 9.

4. UNESCO, "Education for All Global Monitoring Report 2011: The Hidden Crisis: Armed Conflict and Education" (Paris: UNESCO, 2011), 40.

5. Ibid., 132.

6. Sarah Dryden-Peterson, "Barriers to Accessing Education in Conflict-Affected Fragile States: Democratic Republic of Congo" (London: Save the Children, 2010), http://www .savethechildren.org.uk/en/54_11364.htm.

7. UNICEF, "Democratic Republic of the Congo Statistics," http://www.unicef.org/infobycountry/drcongo_statistics .html\#56.

8. Keith M. Lewin, "Improving Access, Equity and Transitions in Education: Creating a Research Agenda," in CREATE Pathways to Access (Brighton, UK: Consortium for Research on Educational Access, Transitions and Equity (CREATE), 2007); World Bank and UNICEF, eds., Abolishing School Fees in Africa: Lessons from Ethiopia, Ghana, Kenya, Malawi, and Mozambique (Washington, DC: World Bank, 2009); Birger Fredriksen, "Rationale, Issues, and 
Conditions for Sustaining the Abolition of School Fees,' in Abolishing School Fees in Africa: Lessons from Ethiopia, Ghana, Kenya, Malawi, and Mozambique, ed. World Bank and UNICEF (Washington, DC: World Bank, 2009).

9. Philip G. Altbach, Tradition and Transition: The International Imperative in Higher Education (Chestnut Hill, MA: Center for International Higher Education, Lynch School of Education, Boston College, 2007), 207.

10. Martin Trow, "Problems in the Transition from Elite to Mass Higher Education," in Policies for Higher Education (Paris: OECD, 1973).

11. United Nations Secretariat, "Annuaries Statistiques, the World Population Prospectus: The 2002 Revision" (Population Division of the Department of Economic and Social Affairs of the United Nations Secretariat, 2001); World Bank, "Higher Education in Developing Countries: Peril and Promise" (Washington, DC: World Bank, 2000), 18.

12. AfriMAP and Open Society Initiative for Southern Africa, "The Democratic Republic of Congo: Effective Delivery of Public Services in the Education Sector" (Johannesburg, South Africa: AfriMAP and The Open Society Initiative for Southern Africa, 2009), 2.

13. Altbach, Tradition and Transition: The International Imperative in Higher Education, 4-5.

14. Ibid., 3 .

15. Xuejuan Su, "Endogenous Determination of Public Budget Allocations across Education Stages," Journal of Development Economics 81 (2006): 439.

16. Anna Obura, Never Again : Educational Reconstruction in Rwanda, Case Studies in Education in Emergencies and Reconstruction (Paris: International Institute for Educational Planning, 2003), 114-21.

17. George Psacharopoulos and Harry Anthony Patrinos, "Returns to Investment in Education: A Further Update," Education Economics 12, no. 2 (2004).

18. John B. Knight and Richard H. Sabot, "Educational Expansion and the Kuznets Effect," American Economic Review 39 (1983).

19. George Psacharopoulos and Jandhyala B. G. Tilak, "Schooling and Equity," in Essays on Poverty, Equity and Growth, ed. George Psacharopoulos (Washington, DC: World Bank, 1991).

20. World Bank, "Accelerating Catch-Up: Tertiary Education for Growth in Sub-Saharan Africa," (Washington, DC: World Bank, 2009).

21. Xuejuan $\mathrm{Su}$, "The Allocation of Public Funds in a Heirarchical Educational System," Journal of Economic Dynamics and Control 28, no. 12 (2004).

22. World Education Forum, "Education in Situations of Emergency and Crisis: Issues Paper" (Dakar, Senegal: World Education Forum, 2000).

23. UNHCR, "Convention and Protocol Relating to the Status of Refugees “ (Geneva: UNHCR, 2010).

24. UNHCR education data is incomplete and unreliable; the numbers presented here should be interpreted with caution.
See Sarah Dryden-Peterson, "Refugee Education: A Global Review” (Geneva: UNHCR, 2011, forthcoming).

25. Gross Enrollment Ratio (GER) is the number of students enrolled at a given level, regardless of age, as a percentage of the population of official school age for that level.

26. Dryden-Peterson, "Refugee Education: A Global Review."

27. Ibid.

28. Margaret Sinclair, "Planning Education in and after Emergencies" (Paris: UNESCO, International Institute of Educational Planning, 2002), 27; UNHCR, "Education Strategy: 2010-2012” (Geneva: UNHCR, 2009).

29. See www.ineesite.org.

30. Sphere Project and Inter-Agency Network for Education in Emergencies, "Integrating Quality Education with Humanitarian Response for Humanitarian Accountability: The Sphere-INEE Companionship" (The Sphere Project, INEE, 2009), http://www.ineesite.org/uploads/documents/ store/Sphere_INEE_paper_FINAL.pdf.

31. Ibid.

32. Finn Stepputat, "Refugees, Security and Development: Current Experience and Strategies of Protection and Assistance in 'the Region of Origin"' (Copenhagen: Danish Institute for International Studies, 2004); Lucy Hovil, "SelfSettled Refugees in Uganda: An Alternative Approach to Displacement?," Journal of Refugee Studies 20, no. 4 (2007); UNHCR, "Convention Plus: Issues Paper on Targeting of Development Assistance” (Geneva: UNHCR, 2004).

33. UNHCR, "UNHCR Education Strategy 2010 -2012 Summary” (Geneva: UNHCR, 2009); Sarah Dryden-Peterson and Lucy Hovil, "A Remaining Hope for Durable Solutions: Local Integration of Refugees and Their Hosts in the Case of Uganda," Refuge 22 (2004); UNHCR, "Refugee Education in Urban Settings, Case Studies from Nairobi, Kampala, Amman, Damascus" (Geneva: UNHCR, Operational Solutions and Transition Section (OSTS), Division for Programme Support and Management (DPSM), 2009). Also, there is a third recognized durable solution, which is resettlement to a third, Western country; however, resettlement is a durable solution for only a small fraction of refugees globally.

34. Personal communication with Ken Davies, Regional Director for Great Lakes, World Food Programme, June 10, 2005.

35. UNHCR and CARE, "Filling the Gap? Informal Schools in Dadaab Refugee Camps: A Joint Study of UNHCR and Care International Kenya" (Dadaab Refugee Camp, Kenya: UNHCR and CARE, 2009).

36. Sarah Dryden-Peterson, "Where Is the Village? Pathways to Integration for African Migrants to the United States" (EdD dissertation, Harvard University, 2009).

37. Sarah Dryden-Peterson, "The Present Is Local, the Future Is Global? Reconciling Current and Future Livelihood Strategies in the Education of Congolese Refugees in Uganda, Refugee Survey Quarterly 25 (2006); Lynn Davies and Christopher Talbot, "Learning in Conflict and Postconflict Contexts," Comparative Education Review 52, no. 4 (2008); 
Rebecca Winthrop and Jackie Kirk, "Learning for a Bright Future: Schooling, Armed Conflict, and Children's WellBeing," Comparative Education Review 52, no. 4 (2008).

38. UNHCR, "Education Strategy: 2010-2012," 4.

39. Dryden-Peterson, "Refugee Education: A Global Review."

40. UNHCR, "The Comprehensive (=Cna) 2010 Budget for Education Is Usd 126 Million," (Geneva: UNHCR, 2009).

41. UNHCR, "Education: 2012 Budget Analysis" (Geneva: UNHCR, 2011).

42. This history is described in further depth in Dryden-Peterson, "Refugee Education: A Global Review."

43. G. Retamal, "Humanitarian Education: Meaning, Origins and Practice" (Geneva: International Bureau of Education, forthcoming), 13.

44. UNHCR Inspection and Evaluation Service, "Review of UNHCR's Refugee Education Activities” (Geneva: UNHCR, 1997), 5.

45. UNHCR, "UNHCR Education Strategy 2010 -2012 Summary."

46. UNHCR, “Education Strategy: 2010-2012," 21.

47. UNHCR, "Education Strategy, 2007-2009: Policy, Challenges and Objectives" (Geneva: UNHCR, 2007), 16.

48. UNHCR, "Annual Report on the DAFI Programme (Albert Einstein German Academic Refugee Initiative), 2008" (Geneva: UNHCR, Operations Solutions and Transition Section, 2009); Women's Refugee Commission, "Living in Limbo: Iraqi Young Women and Men in Jordan" (New York: Women's Refugee Commission, 2009), 6.

49. Personal observation.

50. UNHCR Executive Committee, "Executive Committee Conclusion No. 107 (lviii)-2007: Conclusion on Children at Risk," UNHCR, http://www.unhcr.org/4717625c2.html.

51. UNHCR, "High Commissioner's Dialogue on Protection Challenges, Theme: Protracted Refugee Situations, Chairman's Summary (11 December 2008)," UNHCR, http://www.unhcr.org/refworld/topic,4565c2251a,4782 45f02,496711472,0.html.

52. UNHCR, “Education Strategy: 2010-2012," 36.

53. UNHCR, United Nations High Commissioner for Refugees, "Education Strategy, 2007-2009: Policy, Challenges and Objectives," 16.

54. Claas Morlang and Sheri Watson, "Tertiary Refugee Education Impact and Achievements: 15 Years of DAFI" (Geneva: UNHCR, Technical Support Section Division of Operation Services, 2007), 18.

55. UNHCR, "Annual Report on the DAFI Programme (Albert Einstein German Academic Refugee Initiative), 2008," 4.

56. UNHCR, "Education Strategy: 2010-2012," 21.

57. Morlang and Watson, "Tertiary Refugee Education Impact and Achievements: 15 Years of DAFI," 17; Women's Refugee Commission, "Living in Limbo: Iraqi Young Women and Men in Jordan," 6.

58. UNHCR, "Review of Upper Level Education: Assistance in Four African Countries," (Geneva: Inspection and
Evaluation Service, UNHCR, 1985), 1-2, as quoted in Retamal, "Humanitarian Education: Meaning, Origins and Practice."

59. Dryden-Peterson, "Refugee Education: A Global Review."

60. IIEP, International Institute for Educational Planning, "Guidebook for Planning Education in Emergencies and Reconstruction" (Paris: UNESCO, 2006), 5.

61. World Bank, "Accelerating Catch-Up: Tertiary Education for Growth in Sub-Saharan Africa," xxi.

62. Ibid.

63. Women's Refugee Commission, "Displaced Youth Program" (New York: Women's Refugee Commission, 2009); Theresa Betancourt et al., "Emergency Education and Psychosocial Adjustment: Displaced Chechen Youth in Ingushetia," Forced Migration Review 15 (2002); Marc Sommers, Fear in Bongoland: Burundi Refugees in Urban Tanzania, Refugee and Forced Migration Studies, vol. 8 (New York: Berghahn Books, 2001); International Institute for Educational Planning, "Guidebook for Planning Education in Emergencies and Reconstruction," 1.

64. USAID, “Global Engagement on Entrepreneurship,” USAID, http://www.usaid.gov/press/factsheets/2009/fs091116 .html.

65. Graça Machel, "The Impact of Armed Conflict on Children" (New York: United Nations, 1996), 56.

66. United Nations, "Convention on the Rights of the Child" (1989).

67. INEE, Inter-Agency Network for Education in Emergencies, Minimum Standards for Education in Emergencies, Chronic Crises and Early Reconstruction (Paris: UNESCO, 2004), 49.

68. Women's Refugee Commission, "Living in Limbo: Iraqi Young Women and Men in Jordan."

69. IIEP, International Institute for Educational Planning, "Guidebook for Planning Education in Emergencies and Reconstruction," 2.

70. Winthrop and Kirk, "Learning for a Bright Future: Schooling, Armed Conflict, and Children's Well-Being."

71. Gerald Martone and Hope Neighbor, "The Emergency Alibi," in Human Rights and Refugees, Internally Displaced Persons, and Migrant Workers: Essays in Memory of Joan Fitzpatrick and Arthur Helton, ed. Anne F. Bayefsky, Joan Fitzpatrick, and Arthur C. Helton (Leiden and Boston: M. Nijhoff, 2006), 3.

72. UNHCR, United Nations High Commissioner for Refugees, "Education Strategy, 2007-2009: Policy, Challenges and Objectives."

73. Claas Morlang and Carolina Stolte, "Tertiary Refugee Education in Afghanistan: Vital for Reconstruction," Forced Migration Review 30 (2008): 63. It is important to note that the results of the study on which this article is based are affected by selectivity bias, with refugees who have experienced successful employment post-graduation more likely to be contactable and more likely to respond to the survey. 
74. UNHCR, "Annual Report on the DAFI Programme (Albert Einstein German Academic Refugee Initiative), 2008," 20.

75. Janet Shriberg, "Teaching Well? Educational Reconstruction Efforts and Support to Teachers in Postwar Liberia" (New York: International Rescue Committee, 2007).

76. Peter Buckland, Reshaping the Future: Education and PostConflict Reconstruction (New York: World Bank, 2005).

77. Jens Aage Hansen and Martin Lehmann, "Agents of Change: Universities as Development Hubs," Journal of Cleaner Production 14, no. 9-11 (2006): 828.

78. Martone and Neighbor, "The Emergency Alibi."

79. Buckland, Reshaping the Future: Education and Post-Conflict Reconstruction; World Bank, "Accelerating Catch-Up: Tertiary Education for Growth in Sub-Saharan Africa."

Sarah Dryden-Peterson is a Social Sciences and Humanities Research Council of Canada post-doctoral fellow affiliated with the Comparative International Development Education Centre at the Ontario Institute for Studies in Education at the University of Toronto. She conducts research on the role of schools in the integration of immigrants and refugees, the development of communities, and the transformation of society. Her work is comparative, situated in conflict-affected countries in sub-Saharan Africa and with African Diaspora communities in the United States and Canada. Her most recent publications include "Conflict, Education, and Displacement" (Conflict and Education, 2011); "Bridging
Home: Building relationships between immigrant and long-time resident youth" (Teachers College Record, 2011); "Reconciliation through relationships among teachers and sub-Saharan African families in the U.S.A." (Education and Reconciliation, 2011); "Education as Livelihood for Refugee Children: Emergency, Protracted, and Urban Experiences" (Educating Children in Conflict Zones: Research, Policy, and Practice for Systemic Change, A Tribute to Jackie Kirk, 2011); "Refugee Education: A Global Review" (UNHCR, forthcoming, 2011). Dryden-Peterson has taught middle school in Boston and founded non-profits in Uganda and South Africa. She was a presidential fellow at the Harvard Graduate School of Education, where she earned her doctorate in education in 2009.

(C) Sarah Dryden-Peterson, 2010. This open-access work is licensed under a Creative Commons Attribution-NonCommercial 4.0 International License, which permits use, reproduction and distribution in any medium for non-commercial purposes, provided the original author(s) are credited and the original publication in Refuge: Canada's Journal on Refugees is cited. 